https://helda.helsinki.fi

Emotion work and affective stance in the mathematics classroom: the case of IRE sequences in Finnish classroom interaction

Tainio, Liisa

2015-03-08

Tainio , L \& Laine , A 2015, ' Emotion work and affective stance in the mathematics classroom: the case of IRE sequences in Finnish classroom interaction ' , Educational Studies in Mathematics , vol. 89 , no. 1 , pp. 67-87 . https://doi.org/10.1007/s10649-015-9591-5

http://hdl.handle.net/10138/230231

https://doi.org/10.1007/s10649-015-9591-5

acceptedVersion

Downloaded from Helda, University of Helsinki institutional repository.

This is an electronic reprint of the original article.

This reprint may differ from the original in pagination and typographic detail.

Please cite the original version. 


\title{
Emotion work and affective stance in the mathematics classroom: the case of IRE sequences in Finnish classroom interaction
}

\section{Liisa Tainio · Anu Laine}

University of Helsinki, PB 9 (Siltavuorenpenger 5A), 00014 University of Helsinki, Finland

liisa.tainio@helsinki.fi,anu.laine@helsinki.fi

\begin{abstract}
Although according to the Finnish curriculum the learning environment in mathematics lessons should promote supportive interaction, Finnish pupils' attitudes toward and self-beliefs regarding mathematics deteriorate during basic education. This article investigates emotion work in teacher-student interaction in Finnish mathematics classrooms; the aim is to identify and suggest situational sources for the negative affective stances that seem to prevail among Finnish pupils. For the specific topic of analysis, we chose IRE sequences, especially teachers' responses to pupils' incorrect answers. Our data consist of ten sixth-grade mathematics lessons. Using conversation analysis as our method, we analyze examples that highlight the participants' emotion work displayed in verbal and non-verbal practices. We suggest that it is pedagogically important that teacher practices communicate the message that incorrect answers are appropriate student contributions and that in analyzing interaction in mathematics education it is important to pay attention to the emotional aspects of the interaction.
\end{abstract}

Keywords: emotion work, Finnish classroom interaction, incorrect answers, conversation analysis, mathematics education

\section{Introduction}

Teachers have a central role in advancing social interaction and learning in their classes (Nathan \& Kim 2009, Ingram 2012). Harrison, Clarke, and Ungerer (2007) summarize that a supportive teacher-pupil relationship advances pupils' social accommodation and their orientation to school, and thus is an important foundation for the pupils' future academic careers. Several studies have suggested that the emotional atmosphere in the classroom affects not only pupils' emotional and social experiences but also learning achievements (e.g., Frenzel, Pekrun \& Goetz 2007). Accordingly, individual factors such as motivation, self-beliefs, and emotions have been connected to learning outcomes in numerous studies (e.g., Mägi et al. 2010).

According to the Finnish National Core Curriculum (NC 2004, 17, 164), the learning environment should support interaction, "promote open dialogue," and encourage pupils "to express their thoughts unambiguously and to justify their actions and conclusions.” In international studies such as TIMMS 2011 and Pisa 2009, Finnish pupils' learning achievements in mathematics have been excellent (Mullis et al. 2012, OECD 2010). The pupils' attitudes, beliefs, and motivation, however, could be more positive. Based on a new national longitudinal study, Finnish pupils' attitudes toward mathematics, as well as their self-beliefs and especially self-efficacy beliefs, deteriorate during basic education (Tuohilampi \& Hannula 2013). In sum, in Finland, it seems that students get excellent results but, on average, do not like mathematics or trust their ability to learn it. This has consequences. For instance, among students in primary teacher education, only about one third have studied advanced mathematics in upper secondary school (Kaasila et al. 2008). 
This article investigates emotion work in teacher-student interaction in Finnish mathematics classrooms from the conversation analytic perspective (e.g., Schegloff 2006). The aim is to identify and suggest situational sources for the negative affective stances that seem to prevail among Finnish pupils. The specific focus of the analysis is the emotion work connected to pupils' incorrect answers. The term "emotion work" comes from Hochschild's (2003) study. Hochschild focused on displays of emotion as well as norms and expectations concerning the expression of emotions that regulated professionals' work; he found an orientation to certain "emotional rules" that lead to "emotional labor" between participants in institutional settings (Hochschild 2003). Since emotion work is tied to certain social and institutional positions (Peräkylä 2012) in classroom settings, there is also a division of emotional labor between participants (Tainio 2012). The social norms of classrooms, including the norms for how participants are supposed to respond emotionally, are developed in recurring interactional practices over the course of time (Ingram 2012). In general, teachers' activities are regulated by the principle of affective neutrality, which has been identified as a key feature in modern professional behavior, as well as by displaying certain emotions in order to enhance learning opportunities (Sorjonen \& Peräkylä 2012, Peräkylä 2012).

In the field of psychology, emotion and affect refer to different phenomena. Affect refers to broader psychological, often pre-conscious states of mind, and emotion to the culturally recognized states of the mind that have, for example, bodily indicators (Ruusuvuori 2013). Conversation analysis (CA) has roots in the sociological tradition in which the use of these terms is more varied. Emotion is usually a broader concept that covers such terms as affect and feeling (Sandlund 2004). In addition to sociological research, CA has been developed further, for instance, in linguistically oriented studies of interaction. In these studies, the term affect has been used as an umbrella concept (e.g., Cekaite 2012). For example, Ochs (1996, 410) defined affective stance as "a mood, attitude, feeling, and disposition, as well as degrees of emotional intensity vis-à-vis some focus of concern." Since affect is a difficult concept in terms of analysis, CA researchers prefer to talk about the affective stance, an attitude that is available for analysis through the linguistic and non-verbal behavior of the interlocutors. In linguistically oriented studies, stance is seen as emerging "from a dialogical interaction between interlocutors in particular dialogic and sequential context" that should be "viewed from an intersubjective vantage point" (Kärkkäinen 2006, 700). In CA, the concepts affect and emotion are usually used interchangeably, and affective behavior is analyzed through the observable practices of the affective stance (Sorjonen \& Peräkylä 2012, Ruusuvuori 2013). Here, we adopt the CA view; we use the concepts emotion and affect interchangeably, and the term affective stance when we analyze the indicators of emotional and affective behavior.

In an interaction, the participants in the conversation display their emotions, or, by using conversation analytic terms, affective stances, through verbal and non-verbal resources such as linguistic features, prosody, facial expressions, gestures, and body postures (Goodwin, Cekaite \& Goodwin 2012, Sorjonen \& Peräkylä 2012). The use of the phrase "displaying emotions" does not, in CA research, refer to analyzing the inner emotions or states of mind of the participants but merely to analyzing the observable indicators and practices the participants use in order to show their true - or faked - emotions. Furthermore, those observable practices are shared and understood as such by other participants, which in itself forms the basis for intersubjective understanding. Since face-to-face conversation is multimodal interaction, participants often display their emotions non-lexically, for instance, through facial expressions and prosody. According to Ruusuvuori $(2013,331)$, emotional expressions "need not to be worded"; for example, "a relevant response to a smile can be another smile," although non-verbal expressions are usually intertwined with spoken discourse.

In the CA tradition, the varied displays of affective stances are negotiated in and through interaction, through the public, observable forms of situated participant activities (Goodwin, Cekaite \& Goodwin, 2012). This is in accordance with the theorizing of discursive psychology (Potter \& Wetherell 1987, Evans, Morgan \& Tsatsaroni 2006, Reis \& Barwell 2013), which sees emotion as a thoroughly public phenomenon oriented to and constructed in interaction. In discursive 
psychology, emotions are not treated as originating in the "inner" states of emotions and being expressed publicly through the "outer" displays in interaction (Potter 2006). In this article, we adopt this view in that we analyze participants' affective stances through the publicly available interactional features observable in video-recorded data.

To pinpoint practices in affective stances and emotional work via a phenomenon participants face in classroom interactions, we chose teachers' responses to pupils' incorrect answers. Incorrect pupil answers form a common paradox in classroom interaction. They are extremely significant, since they give the teacher information about pupil achievement and possible gaps in knowledge (Lemke 1990, 27-28). However, incorrect pupil answers are not always welcomed by teachers or pupils since offering an unpredictable, dispreferred answer in an interaction, such as a wrong answer, is always a potentially problematic, face-threatening activity for the speaker and the recipients (for facethreatening acts, see Brown \& Levinson 1987).

We take as our starting point the assumption that the treatment of "incorrect" answers carries a strong "pedagogical message" (Seedhouse 2004, Roth \& Gardener 2012, Kääntä 2010). This is why teachers' evaluative responses to students' incorrect answers are one of the most important practices for increasing pupils' motivation to learn and participate in the classroom (see also Heritage \& Heritage 2013).

In this article, we present an analysis of Finnish mathematics lessons taught by different teachers in the sixth grade of Finnish comprehensive schools. Pupils in the sixth grade are aged 12 to 13 . The aim of our analysis was to find answers to the following questions:

- What are the ways in which teachers respond to pupils' incorrect answers in Finnish mathematics classrooms?

- What are the consequences of varied teacher responses for student participation in these contexts?

- How are the affective stances carried out and treated in interactions by the participants, and what are the possible consequences of these activities in terms of "promoting open dialogue" in mathematics education (NC 2004, 17)?

By analyzing sequences that include incorrect pupil answers and teacher responses, we intend to identify practices that might serve as sources of decreasing positive emotional engagement. We will not offer a general explication of the manifold problems that cause the deterioration in pupil attitudes, motivation, and self-beliefs in mathematics education in Finland (see Tuohilampi \& Hannula 2013). However, our intention is to offer new perspectives on the discussion of this phenomenon (see Hannula 2012).

\section{Interaction and affective stances in mathematics classroom through conversation analysis}

CA studies focused on mathematics education have been conducted only for about 15 years (Forrester \& Pike 1998). Forrester and Pike investigated the orderly and sequential development of strategies used in the process of learning to estimate. The researchers appreciated the CA method for offering analytic tools for uncovering the situated characteristics of pedagogic interaction. CA tools were later used to uncover the intricate characteristics of pedagogic interaction, especially the role of language in learning mathematics (e.g., Barwell 2003). Mushin, Gardner and Munro (2013) showed that language could play a significant role in failing to understand and in demonstrating the (non)understanding of mathematical concepts. Teachers might, mainly due to a pupil's language competence, often end up explaining a problem they assume the pupil has instead of trying to determine the actual problem the pupil is trying to formulate (Koole 2012b). However, pupils may, through routine IRE sequences and with the help of teacher guidance, manage to orient themselves to understand demanding tasks, such as three-dimensional geometry, which was demonstrated in Roth and Gardener's study (2012). Ingram (2012) examined the variation in mathematics teachers' 
practices, and the consequences of different practices of carrying out mathematical tasks for the pupils' experience of the nature of mathematics as a science. What is interesting in these studies is that even though they carefully analyzed delicate sequences in which pupils encountered problems in learning, the studies did not take up the emotional dimensions of dealing with the problems.

However, starting from the social aspects of mathematics education, Emanuelsson and Sahlström (2008) analyzed lesson episodes in which the students' emotional expressions ultimately influenced the formation of mediated content knowledge in classroom interaction. Emanuelsson and Sahlström (2008) showed how the students' emotions were displayed; the students expressed emotional criticism of teaching in Swedish classrooms that made the teacher simplify and even trivialize the mathematical content in question. The researchers called this trivialization the "price of participation." To further demonstrate the effect of students' affective contributions, the researchers also presented sequences from a U.S. classroom. There, the mathematical content remained complex, but as a result, there was much less student participation and no proof from the students that they had understood the content. Our study explicitly analyzes affective stances and explores the consequences of students' emotion displays during the course of the interaction. Our analysis intends to investigate affective stances in the spirit of Emanuelsson and Sahlström (2008).

Studying emotional and affective stances in the details of interactional practices in mathematics lessons has not been widely investigated, not even with other methods of interaction analysis in addition to CA (Hannula 2012). Evans, Morgan and Tsatsarouni (2006) explored emotion in classroom interaction in the framework of discursive psychology, and with analytic tools of discourse analysis. Järvelä, Järvenoja and Veermans (2008) studied the dynamics of motivation in socially shared learning. This article contributes to the field of educational research in mathematics by locating and analyzing the emotion work demonstrated in the verbal and non-verbal practices of affective stance taken during the pedagogically demanding work that teachers perform while responding to pupils' incorrect answers.

\section{Methodological framework}

$\mathrm{CA}$ is a qualitative approach that analyzes naturally occurring interactions in order to examine the normative organization of ordinary conversational conduct (Schegloff 2006). The CA approach focuses on describing the organization of interactional sequences. The aim is to analyze the micro-contexts of interaction to highlight the work participants do themselves as they interpret preceding turns-at-talk by other participants. CA is highly effective in revealing the orderly practices of interaction (Goodwin \& Heritage 1990).

Analyses of classroom interaction have identified as one of the basic structures of classroom interaction the three-part sequence usually referred to as the Initiation-Response-Evaluation sequence (IRE or IRF; see e.g. Mehan 1979, Ingram 2012). In addition, it has been identified as the pervasive interactional building block of pedagogic interaction in contexts outside the classroom, such as in everyday interactions where learning is one of the purposes of the conversation (Drew 1981). Although many doubts exist about the effectiveness and appropriateness of the IRE sequence in fostering student learning (e.g., Bauersfeld 1988, Macbeth 2003, Koole 2012a) and although IRE is not obligatory or even used in all classrooms, this sequence remains the main interactional means for putting learning into practice in classroom settings (Heritage \& Heritage 2013). However, in some recent studies IRE's importance has been emphasized as a predictable, routine practice for student learning (Heritage \& Heritage 2013, Nathan \& Kim 2009, Ingram 2012). In an analysis of mathematics classrooms, Roth and Gardener $(2012,336)$ considered the IRE sequence an integral part of classroom routine and an important tool for teaching and learning.

\section{Data and the focus of the analysis}


Our data consist of ten mathematics lessons in the sixth grade of ordinary Finnish comprehensive schools in the Helsinki area, videotaped during one month. The number of pupils in the classrooms ranged from 17 to 26 . The data were recorded using three video cameras in each classroom. The data were transcribed using the notation and symbols developed and used in CA. It pays attention not only to the talk and pauses but also to non-verbal aspects of conversational conduct.

In our data, the lesson topics varied, although most of the classes dealt with studying fractions or calculating time. For our purposes, the lesson topic is not as significant as the teaching methods used. As argued earlier and confirmed by our data, the teaching approaches in Finnish mathematics education are traditional, and consist mainly of either teacher-led frontal teaching for the whole group or individual work on exercises or tasks available in the learning material, such as textbooks. In our analysis, the number and length of teacher-led phases in a lesson vary, and in our analysis, we concentrated only on the phases during which the teacher's talk is audible to everybody and there is room for student answers.

Because of the teaching format in use during the lesson and the variation in individual instructional practices among teachers (c.f. Ingram 2012), the number of incorrect answers identified in each lesson varied from zero to 16 . The total number of incorrect answers in our data is 36 . We identified answers as incorrect by attending to the observable signs found in the actions of the teacher or other participants. This identification process was conducted by using the analytical findings offered by the CA tradition. In the following, we will explicate the interactional features that help identify incorrect answers. ${ }^{1}$

From the CA point of view, the basic building block of all interaction is an adjacency pair. This term refers to two conversational actions in which the first turn initiates a certain kind of second turn. For example, an invitation, as the first pair part of an adjacency pair, makes consequentially relevant the acceptance or rejection of the invitation as the second pair part. The IRE sequence can be seen as consisting of two adjacency pairs, where the first is the Initiation and the Response, and the second the Response and its Evaluation (Mehan 1979). These two adjacency pairs are tightly intertwined, however. Evaluations are enacted in response to the design of the second turn, the Response, and thus also in response to the design of the first turn, the Initiation (Seedhouse 2004). Evaluation of the preferred second pair part (e.g., a correct answer) is produced without pauses, using acknowledgement markers that convey acceptance or by repeating at least a part of the preceding turn with a new turn pronounced with falling intonation (see Mehan 1979, Hellerman 2003). Consequently, if the second pair part (e.g., answer) is not what was sought by the first pair part (e.g., question), the reception (e.g., evaluation) of the second turn by the teacher is conducted through practices that are typical for a dispreferred action. This means that the Evaluation is conducted with delays, and by using specific verbal formulations and certain non-verbal practices, such as abrupt body movements or a discourse particle with rising intonation (Hellermann 2003). In addition, the Evaluation that treats the previous turn, the Response, as problematic initiates the expansion of the sequence: The ongoing sequence will not be closed until the problem is solved and, sometimes, an account of the problem given (Kääntä 2010, Roth and Gardener 2012). This is in contrast to positive Evaluations, which are produced as preferred actions and immediately close the sequence.

\section{The variety of teacher evaluative responses}

\footnotetext{
${ }^{1}$ In this analysis, our intention is to analyze only the incorrect answers that are marked as such with certain interactional practices conducted by the teacher and the peers. That leaves out answers that are incorrect (from the mathematical point of view) but are not treated as incorrect by the participants. In addition, answers that are correct but treated as incorrect by the participants would be included in the data set. This decision was made since our focus is to analyze the practices of displaying emotions when a pupil produces an answer that is treated as incorrect.
} 
Since treating a student answer as incorrect is often a face-threatening, affective act and a dispreferred action in classroom interaction, and since the formulation of the Evaluation is influenced by the preceding parts of the IRE sequence, the variation in these turns is broad. Using concepts and practices identified in CA, we identified seven types of teacher evaluations in our data (see Table 1). These categories illustrate only the activities carried out in our data and thus cannot be treated as a complete list of possible options. However, since our description is based on a detailed analysis of the data and takes into account earlier research on classroom interaction, we argue that the categories can be treated as the most typical responses to incorrect pupil answers.

The third turn, the Evaluation, opens up the expansion of the sequence in which the correction or repair is conducted until the teacher is able to give a positive evaluation to the pupil and start a new sequence. Since this activity is not always straightforward, it might need more than one evaluative response by the teacher, expanding the IRE sequence into more complex sequences with recurring evaluation-initiations and responses within the sequence. This means that even though we identified 36 incorrect answers, we found 46 Evaluative responses to the answers. The teacher's evaluative responses thus may consist of several steps; for example, after a minimal response the teacher may allocate the turn to another student, or after a correction s/he may give an account of the student's answer. In Table 1, we provide an overall picture of the types and the division of the evaluative responses in the data, as well as a short description of the action in question.

Table 1 The variety of teacher Evaluative responses to pupils' incorrect answers

\begin{tabular}{|c|c|c|}
\hline T: Evaluative response & Description & Number \\
\hline Minimal response & $\begin{array}{l}\text { Teacher responds with a discourse particle (e.g., yeah, ok, } \\
\text { oh). }\end{array}$ & 10 \\
\hline Turn-allocation to another $\mathrm{S}$ & Teacher gives the turn to another student. & 7 \\
\hline Correction & Teacher responds by giving the correct answer. & 4 \\
\hline Open question & $\begin{array}{l}\text { Teacher responds with a question word, e.g., what, which, } \\
\text { why. }\end{array}$ & 3 \\
\hline (Modified) repetition of the question & $\begin{array}{l}\text { Teacher repeats (and sometimes modifies) part of her/his } \\
\text { own question. }\end{array}$ & 5 \\
\hline (Modified) repetition of the answer & $\begin{array}{l}\text { Teacher repeats (and sometimes modifies) part of the } \\
\text { student's answer. }\end{array}$ & 9 \\
\hline New question based on the answer & Teacher asks a new question based on the student's answer. & $\begin{array}{l}8 \\
46 \text { total }\end{array}$ \\
\hline
\end{tabular}

In the following, we analyze three examples of interactions in which a pupil's incorrect answer is followed by the teacher's evaluative responses. We have chosen as examples a selection of instances in which the teachers use several of these types of evaluation in their responses. With the help of the analyses of these extracts, we intend to highlight the emotion work embedded in the interactional sequences in classroom interaction.

\section{Examples of emotion work embedded in IRE sequences}

The following three examples illustrate different dimensions of emotion work in classroom interaction. Extract 1 demonstrates the ways in which incorrect answers can be treated in classroom interaction as incidental mistakes or accidents that are responded to by the participants by taking affective stances that display affiliation and humor. In 
extract 2, the participants treat the incorrect pupil answer as an embarrassing incident, which the teacher responds to with affective responses. The last extract (3) shows an episode of an interaction that, after displays of varied, mixed affective stance takings and expressions of emotion, leads to a conclusion in which the student displays positive stance taking.

6.1 Example 1: Modified repetition of the answer

In classroom interactions, teachers repeat student answers in IRE sequences to show acceptance of the student answer and rejection (e.g., Hellermann 2003, Macbeth 2004). The different purposes are observable through non-verbal resources, such as intonation, gaze, and body posture, as well as through linguistic features in cases where the repetition is modified.

In everyday conversations, repeating part of the problematic turn is the most frequently used practice to show the speaker the source of the problem in the preceding turn (Schegloff et al. 1977). In our classroom data, we found nine cases of (modified) repetitions of a pupil's answer. In these cases, the pupil's answer was not ignored but taken into account in the design of the teacher evaluation and the progress of the pedagogic interaction.

In the first extract, the teacher reads aloud the task in the textbook verbatim (lines 1-3). The pupils display their willingness to answer the easily anticipated question by raising their hands. In the examples, the teacher is marked with a $\mathrm{T}$, and the students are marked with first name pseudonyms. ${ }^{2}$

\section{Example 1 (Ls6c:496-511)}

$01 \mathrm{~T}$ : "bussi lähtee [Vammalasta Helsinkiin kello yhdeksän the bus leaves/Vammala for Helsinki at nine ((first Irma and then 10 other pupils raise their hands one after another during the question))

02 viisitoista; (.) matka kestää kaksi tuntia viisikymmentä fifteen, (.) the trip takes two hours and fifty

03 minuuttia; (.) [milloin (.) bussi on Helsingissä”, Irma, minutes, (.) [when (.) is the bus in Helsinki," Irma, [((teacher looks at the class, turns her gaze to Irma $))$

04 Irma: [ykstoist [nolla viis. [five past[ eleven [((Irma looks at the teacher $))$ [((teacher gazes at the textbook))

05 (.)

$06 \mathrm{~T}$ : sä [sait $\uparrow$ ykstoist nolla [viis? you [got $\uparrow$ five past ele[ven?

[((13 pupils raise [their hands during lines 6-10; Irma picks up an eraser $))$ [((teacher gazes at Irma, smiling))

\footnotetext{
2 The transcription symbols are available in the Appendix. The translations in English are in italics under the original Finnish turns.
} 
$08 \mathrm{~T}$ :

sul on, (.) [tosi, (.) eks[presvuoro.

you have, (.) [a real, (.) ex[press buss.

[((teacher sm[iles $))$

[((Irma smiles $))$

09

10 T: Ella?

11 Ella: kakstoist nolla [viis?

five past [twelve?

$12 \mathrm{~T}$ :

[kakstoist nolla viis. (.) Ella meni

[five past twelve. (.) Ella did not take

13

vakiovuorolla [tuli tuntii myöhemmin perille;

the express bus and [arrived there an hour later, [((teacher smiles $))$

(1.1) ((pupils are smiling, also Irma $))$

$15 \mathrm{~T}$ :

yhen tunnin heitto.

((to Irma:)) a mistake of one hour.

During the teacher's question (lines 1-3), Irma is the first one to raise her hand, and the teacher allocates the turn to her (line 3). She answers incorrectly (line 4). After a short pause, the teacher repeats her answer by addressing a remark to her in the second person singular (you), with a turn that finishes with a rising intonation (line 6). A rising intonation in the teacher's evaluation turn usually marks the answer as incomplete or incorrect (Hellermann 2003, Tainio 2012). Here the other students, as well as Irma herself, interpret the teacher's remark as a sign of an incorrect answer even if it does not linguistically show that the answer is incorrect. The teacher merely treats the answer as Irma's individual result. Nevertheless, the other students start to raise their hands, and Irma picks up an eraser (during lines 6-10).

In terms of emotion work, in this episode the participants share the emotions that are observable in the facial expressions, such as smiles, and through a smiling voice. After Irma's answer, the teacher offers a humorous remark with a smiling voice and frames the turn with a smile even before uttering it (lines 6-8). In the interaction, participants can frame their contributions by displaying facial expressions to convey emotions to the recipients in order to give them a clue to the mode in which the following turn is to be interpreted (Peräkylä \& Ruusuvuori 2012). During the teacher's turn, Irma starts to smile together with the teacher (line 8), but then other pupils gradually start smiling together with them (lines 10-13). At the end of the extract (line 14), almost all the students are smiling. Since affective stances are usually attended by the participants, a shared emotion can be achieved as the result (Peräkylä 2012). In this extract, the teacher's affective stance is shared by the addressee and the other pupils. There are no malicious facial expressions or laughing among the students, and the teacher first leads the episode matter-of-factly (e.g., lines 5-6, 10-12, and 15), and then smiling and using a humorous mode (lines 8 and 12-13).

The practice of repeating the whole pupil answer or part of the answer with or without modifications is common that in our data seems to encourage the students - the respondent or the others - to try to reach the correct answer. In this extract, the teacher's use of humor in connection with the incorrect answers seems to encourage pupil participation, which continues in a similar fashion after this episode. The teacher treats Irma's incorrect answer as a mistake rather than as evidence of her misunderstanding. Since the task in question is merely a straightforward calculation and the answer is presented as the last one in a chain of answers to similar questions preceding this extract, the teacher has 
pedagogical grounds for treating the problem as accidental. Overall, in this classroom the participants treat incorrect answers as a normal, appropriate part of classroom interaction, and nobody laughs at pupils who produce incorrect answers. This is not the case in some of the other classes in our data.

\subsection{Example 2: Modified repetition of the question}

One of the most typical practices in classroom interaction is that the teacher reformulates his/her question when s/he does not get the (expected) answer from students (Macbeth 2004). In our data, we identified three types of reformulated questions, namely, an open question, a modified repetition of the question, and a new question based on the answer. The first and last ones, an open question and a new question based on the answer, are described in the analysis of the next example. Here the teacher repeats the whole question or part of the question either in exactly the same way or by modifying parts of it. This practice is rarely used in everyday interaction since, in this type of repetition or reformulation of the question, the answer is not taken into account in the verbal design of the next action. However, by partly repeating and modifying the question the teacher usually displays some information about the nature of the problem in the answer.

In this example, the pupils are converting fractions to percentages and vice versa. To help the students understand the principles of this process, the teacher drew a circle on the blackboard and uses it when talking about fractions and percentages (see line 12). The teacher is standing in front of the blackboard, writing down the correct answers to the exercises.

\section{Example 2. (Km6A:691-706)}

$01 \mathrm{~T}$ : $\quad$ kuinka paljo yks viidesosaa on how much is a fifth

02 prosenttheina. as a percentage.

(0.2) ((four pupils raise their hands, including Sabina; the teacher looks around the class and ends up looking at her))

04 T: Sabina.

06 Sabina: nolla? ((looking at the teacher; rests her right elbow on the zero?

(1.0) ((Sabina smiles a little, facial expression freezes for a moment, looking at the teacher; T: gazes at Sabina, her body posture frozen ))

08 Sabina: .hh $£$ aa $£(($ gazes at the teacher $))$ (0.9) ((intent mutual gaze))

10 Sabina: yks sa[das? one hu[ndreth? (.)]

[ hä, ] [hä,] [((S:wrinkles eyebrows $))][((S:$ moving hand quickly from the chin outwards and back]; then a little smile $)$ )

[((T: smile and quick laughter]; starts moving again; 
11 T: $\quad £ h £($.) kuinka paljo toi om prosentteina $£$ hh£ (.) how much is it in percentages this one fifth. (0.2) you had the circle,

$14 \mathrm{~T}$ : ja se oli jaettuv viitee osaa. it was divided into five parts.

$16 \mathrm{~T}: \quad$ kuinka paljo on sillon yks, (0.4) viidesosa then how much is one, (0.4) fifth prosentteina. in percentages.

19 T: Eemil?

20 Eemil: kahkskyt prosenttii. twenty percent. twenty percent.

After the teacher's question (lines 1-2), several pupils raise their hands. This usually is a sign that the question was not too difficult. The teacher allocates the turn to Sabina, who answers incorrectly (line 6). The teacher does not respond verbally, but her body posture freezes, and she continues to look at Sabina, thus indicating nonverbally that the answer was incorrect and that she is expecting a new answer (Kääntä 2010, 197-210). Sabina verbalizes her hesitation with a quick inhalation and a vocal expression (line 8), and then her facial expression freezes for a moment, thus indicating that she has received the teacher's non-verbal message about a problem in her answer. Then Sabina tries again, marking the answer with rising intonation, and wrinkles her eyebrows (line 10). After a small pause, she produces a particle that in Finnish can be used as a laughing particle as well as a vernacular way to say 'what' (Haakana 2011). While uttering this particle, she moves her hand quickly from her chin and back to the earlier position, and looks at the teacher. Then Sabina smiles briefly. The teacher looks at her, relaxes her body posture and briefly laughs, and then quickly moves her gaze to the other students (line 10). Sabina remains smiling a bit, looking first down at her textbook and, then, after a while, again up at the teacher. The teacher repeats the question with minimal modifications, addressing it to other pupils (lines 11-12) and adding more explanation that refers to the circle (lines 12-14). After yet another minimally modified repetition of her original question (lines 16-17), she gets an answer from Eemil. Eemil's answer is treated as correct: The teacher repeats the answer with falling intonation and nods (line 22).

On this occasion, the emotion work is conducted mostly with non-verbal embodied activities, with facial expressions and gestures. Verbally, the teacher repeats her question in an almost identical form after one pupil twice failed to answer the original question correctly. The first respondent displays her emotion non-verbally with her facial expressions, gestures, laughter, and smile (lines 6-10). Although the teacher at first presumably acts upon a pedagogical 
intention to allow a student who has answered incorrectly another attempt (cf. Koole 2012a), the teacher does not rephrase her question to Sabina or repeat her answers in order to indicate the problem. Instead, the teacher engages in an episode in which she responds to Sabina's emotional displays with verbal and facial expressions (cf. Reis \& Barwell 2013). The division of emotional labor is guided by the demand for professional neutrality as well as by the preference for sharing certain feelings and either showing or restraining from showing other feelings (Peräkylä 2012). Here the teacher responds with emotional expressions, showing tension by her frozen body posture and intent gaze, to the pupil in the context of the pupil's incorrect answer. Even when the teacher finally releases her posture and then laughs briefly, the participants may interpret uttering an incorrect answer as a problematic activity in the classroom setting.

\subsection{Example 3: Open question and a new question based on the answer}

In everyday conversation, open questions as responses to preceding turns are used as repair initiators that do not actually point out what the trouble is in the previous turn (Schegloff et al. 1977). Open questions do not state to the producer the features that make the turn problematic, and the producer of the problem turn usually repeats it in its entirety. This interactional feature makes these types of evaluative responses pedagogically useful, since they ask the student to reformulate her/his answer without hinting where the trouble lies. However, for the same reason they can also be too challenging if the student has no idea why the answer was incorrect.

Instead, in a practice of formulating a new question based on the student answer, the student answer is used as a building block for the ongoing pedagogical interaction that challenges the student to think about the problem from another angle. These teacher responses were common in our data (eight cases), and even though the pupils who had offered incorrect answers did not always solve the problem by themselves, the problems were always solved during the course of the sequence by other pupils. Thus, this practice is effective from the point of view of content understanding.

In the next example, the pupils in the classroom are working individually, solving tasks presented in their textbooks. Jaakko and the teacher are sitting at the back of the classroom, discussing aloud so that everyone in the classroom hears them. Some of the pupils are following the conversation by looking at them.

Jaakko has been working on the task of how much tickets would cost for four persons if they had a group reduction of 25 percent. The full price for one person, 24.80 euros, has been mentioned. Jaakko tried to solve the problem, but when he checked the textbook, which includes the right answers, he found that his solution was incorrect. A bit agitated, he turns toward the teacher, raises his voice, and asks whether there is a typing error in the textbook. The teacher immediately turns toward Jaakko, leans forward, looks at the textbook, displaying with her non-verbal behavior that she has received the turn and the affective stance it mediates. The teacher starts to guide Jaakko in finding out what went wrong in his reasoning. During her explanation, Jaakko brings the textbook in front of his mouth and continues looking at the teacher, responding minimally to her explanations. During the first 11 lines, the teacher and Jaakko are looking intently at each other. In lines 1-2, the teacher asks Jaakko what the calculation of 25 percent of the price actually means, in terms of arriving at the right procedure and the final answer.

\section{Example 3 (Mm6c:1659-1708)}

$01 \mathrm{~T}: \quad \operatorname{nim}($.$) minkä itse asias tuloksen sä$ so (.) what actually is the result

02 saat siitä. you get.

03 Jaakko: kuus pistek kaks, 
six point two,

04

$05 \mathrm{~T}$ : mitä se tarkottaa mikä se on se

what does that mean what is this

06

07 Jaakko: yhen hengeh hinta.

the price for one person.

08 T: onko,

is it,

09

10 T: mietippäv (.) voiko? (.) ku se

think again. (.) can it be? (.) when the

11

12

alkuperänen hinta oli [yli

original price was ov[er

[((teacher reaches forward and points to Jaakko's

exercise book where he has the written the calculation))

kaks[kytneljä, (0.4) euroa.

twen [ty four, (0.4) euros.

[((teacher and Jaakko look at the exercise book, teacher reaches to

it; Jaakko puts down the textbook and orients to the exercise book))

13

(.)

14 Jaakko: $\mathrm{mm}$ ?

$m m$ ?

$15 \mathrm{~T}$ : $\quad[\operatorname{nim}($.$) voiko se [hinta$

[so (.) can the pri[ce

[((teacher and Ja[akko look at each other $))$

[((teacher puts the exercise book forward on Jaakko's desk, and leans backward again; intensive mutual gaze continues))

16

kahenkymmenenviiden prosentin

after the reduction of 25 percent

17 alennuksen jälkeen ollak kuus euroo.

be six euros.

18

(0.4) ((intensive mutual gaze continues $))$

19 T: ja risat.

and a little bit more.

20

(1.5) ((mutual gaze))

21 T: o[nks se mahdollistakaa.

is[ it even possible.

[((Jaakko turns his gaze to the exercise book)) 
23 T: kuulostaako järkevältä.

does it sound reasonable.

24

25 Jaakko: $\mathrm{m}[\because: \mathrm{m}$ ?

[((Jaakko turns his gaze quickly to teacher $))$

26

(0.8) ((mutual gaze))

27 T: $\quad$ ihanko totta?

are you $\uparrow$ sure?

28 Jaakko: no [jos, he he (.) $\mathrm{p}(\mathrm{h})$ uolet [tästä. (.) ni se on wel[l if, he he (.) half of [this. (.) so it is [((Jaakko: gazes at the e [xercise book))

[(

29

kakstoista] pisten [neljä.

twelve ] point [four.

smiles)) ] [

[((Jaakko gazes at teacher; mutual gaze $))$

30 T: nii. (.) [aatteles se on $\mathrm{p}$ [uolet.

yes. (.) [ think again it [is half of it.

[((teacher leans [forward toward Jaakko))

[((teacher raises hand and moves it downward $))$

31

(1.0) ((mutual gaze continues $))$

$32 \mathrm{~T}$ : nyt sä et saa edes puolia alennusta.

and now you don't get even fifty percent reduction.

34

(.) niin [ku sä väitit että se on kuus

(.) when[ you said it was six

[((teacher smiles $))$

35

ja ri[sat.

and [ a bit more£.

[((Jaakko's gazes at the exercise book, raising his hand to his cheek))

36 Jaakko: [UPPPSTA. (.) mä laskin sit täv vähäv vääri.=

[OOPS. (.) then I did calculate this a little bit wrong.

[((teacher looks at Jaakko, who looks at the exercise book))

$37 \mathrm{~T}: \quad=$ [et $\mathrm{sä} \uparrow \underline{o o l}$ laskenum $\uparrow$ mitään väärin vaan

[ no you $\uparrow$ did not calculate $\uparrow$ wrong at all but

[((teacher shakes her head; mutual gaze continues $))$

mikä se on itse asiassa se kuus euroo.

what actually is this six euros.

39

(3.1) ((teacher looks at Jaakko, whose gaze is on the exercise book; Jaakko strokes his hair))

40 Jaakko: [koko sen >ryhmän matka vai<.=

[the sum for > the whole group or $<.=$

[((Jaakko's gaze on teacher; mutual gaze $))$ 
$41 \mathrm{~T}: \quad=[\mathrm{ei} .=$

$=[$ no. $=$

[((teacher's short smile) $)$

42 Jaakko: $=[\mathrm{EM} \uparrow[$ MINÄ TIEdä.

$=\left[\uparrow I D\left[O N^{\prime} T\right.\right.$ KNOw.

[((Jaakko's gaze on exercise book))

[

$43 \mathrm{~T}$ :

[jos se on kakskytviis[prosenttia siit

[if it is twenty five [percent of

[((teacher looks at Jaa[kko))

[((Jaakko gazes at teacher, strokes his hair $))$

44

tost luvusta.

that amount.

45

(1.2) ((mutual gaze))

46 Jaakko: niin ni onks pitääks se [kūus [vä[hentäät tästä.

so then is should this [ six b[e t[aken from that.

[ [ ( (Ja[akko points to the exercise book $))$

$47 \mathrm{~T}$ : $[($ tea[ch[er [nods $))$

[just ni.[

[exactly. ((nodding))

After explaining the first steps in solving this task, the teacher asks a question that checks whether the pupil has understood the procedures that he has carried out. Instead of giving the answer to this question, Jaakko offers the result for the calculation, which, in fact, is correct (line 3). After the answer, there is a pause, and the teacher reformulates her question to get Jaakko to understand the gist of the question. After another answer (line 7) that indicates that the pupil is only partly on the right track, the teacher asks an open question (line 8), which is followed by a pause, and then by other questions that offer more information (lines 10-17). The teacher tries to get the pupil to estimate what kind of a result would be reasonable (Forrester \& Pike 1998). During the teacher's questions, the pupil looks either at the teacher or his exercise book; the teacher looks intently at the pupil. After several teacher questions, Jaakko offers an answer that shows that he has not yet been able to understand the line of reasoning the teacher is pointing to (line 25).

After Jaakko's minimal response, there is a pause. The intensive mutual gaze continues, and again the teacher asks an open question that conveys doubt (line 27). Jaakko answers by explaining his calculation (lines 28-29). During his turn, he laughs briefly and gives the explanation smiling. Jaakko's laugh in this context cannot be interpreted as a display of amusement but instead as a display of embarrassment (Haakana 2001). The teacher does not share this emotion display. She continues by using Jaakko's answer as a starting point for an explanation (lines 30-35). At the end of her turn, she smiles; during that part of the turn, she directly points out the wrong line of pupil thinking (you said, line 34). During this episode, the pupil and the teacher have been expressing opposing conclusions about the gist of the task. Now Jaakko gives up and displays emotion: He utters a response loudly and admits his mistake (line 36).

The teacher quickly responds to Jaakko's affective turn. She disagrees with Jaakko's understanding, claims that he has calculated correctly, and once again repeats the original question about the meaning of the result of the calculation (lines 38-39). There is a longish pause, during which Jaakko looks at his exercise book, displaying seriousness, and strokes his hair. He does not yet, however, get the point of the teacher's questions and answers incorrectly with a suggestion that clearly shows he is confused (line 40). The teacher gives a brief smile and a negative evaluation (line 
41). At this point, Jaakko openly displays his emotions and disappointment and exclaims loudly that he does not know (line 42). Even if the teacher has been raising the stakes up to this point (Reis \& Barwell 2013), she now responds immediately to his emotional expression, and gives him the right answer with an overlapping turn (line 43). Thus, the teacher does not share Jaakko's emotion but takes it into account and gives him the clue he apparently needs. After the teacher's clue, Jaakko finally understands his previous mistake. He starts to ask questions that show progress in solving the task (line 46). The teacher's activities in this sequence can be described as funneling practices (Bauersfeld 1988).

An open question (lines 8 and 27) initiates a repair by the respondent. Nevertheless, the question does not point out the problem in the answer. Jaakko subsequently fails to find the answer or the right direction with the help of these questions, and the teacher has to reformulate her questions several times. In our data, this seems to be the result for all three cases of open questions: They do not actually help the pupil find the right line of reasoning, even if open-ended question, especially questions asking for justifications are needed to deepen pupils' understanding (Sahin \& Kulm 2008). In this extract, the teacher recurrently uses open questions and reformulated questions to guide the pupil, and the emotion work of both participants is clearly observable. The teacher responds to the pupil's emotional reactions (lines 28-29), the first exclamation of disappointment (line 36), and the second, more agitated exclamation of disappointment (line 42). In all these cases, the teacher stays calm, but responds to the affective aspects of the pupil turns by offering explanations and finally the required clue. These teacher responses are conducted immediately, the last one even overlapping with the pupil's turn. This episode ends with satisfaction displayed by both participants.

In this extract, teacher practices carry the pedagogical message that the incorrect answers are not face-threatening acts but normal, appropriate answers in classroom interaction. This practice can be used in contexts where the pupil is partially on the right track. It conveys to the pupil that his/her efforts are appreciated and that the teacher trusts the pupil's ability to answer correctly with some guidance. This is a good way to foster pupils' independent thinking and support pupils' learning to justify their solutions (Sahin \& Kulm 2008). From the point of view of emotion work, this kind of episode wavers on the edge of failure because it can end with frustration and possibly even a lack of motivation.

\section{Discussion}

In an interaction, emotion takes on public forms, and affective stances are attended to by all participants (Goodwin, Cekaite \& Goodwin 2012). In institutional settings, participants, and especially professionals, orient to certain principles of emotional work during the interaction (Peräkylä 2012). In classrooms, where the main purpose of the activities is to get the pupils to learn, the emotion work of the teacher and the pupil differs. Similar to other professionals, teachers are faced with the demand for "professional neutrality" during their work in the classroom. Yet they are also expected to display certain emotions to help pupils enjoy the learning process and to motivate them in their tasks. In the Finnish national curriculum, the goals of supporting "open dialogue" in interaction and getting pupils to "learn to trust themselves" (NC 2004, 17, 164) cannot be reached without taking emotion work into account in pedagogic interaction.

In this article, we have analyzed emotion work in Finnish mathematics classrooms by using the pervasive interactional building block of classroom interaction, namely, the IRE, as a starting point for our analysis. Even if there are many doubts concerning the suitability of IRE in fostering learning, IRE sequences are not only frequently used but also offer pupils and students a practical and well-known routine that supports their thinking processes and promotes learning (Roth \& Gardener 2012, Heritage \& Heritage 2013). In IRE sequences and especially through the teacher's evaluation of an incorrect pupil answer, the emotion work is substantial. Overall, the number of incorrect answers in the ten lessons (36) shows that incorrect answers are rare. This leads us to ask if teachers are intentionally minimizing the possibility of incorrect/wrong student answers when they ask questions that are easy in terms of content, cognitive 
demand, and even procedure. In our data, consisting of ten sixth-grade mathematics lessons, we chose to analyze three examples that illustrate the different kinds of emotion work carried out through IRE sequences in classrooms.

We are interested in emotion work in mathematics classrooms since Finnish pupils' and students' attitudes toward mathematics education become alarmingly negative during basic education (Tuohilampi \& Hannula 2013), and very few studies have focused on the dynamics of emotional or motivational states in the classroom (Hannula 2012). In responding to incorrect answers, teachers, consciously or accidentally, display their stance toward student mistakes and failures. If these displays are recurrently charged with embarrassment or disconcertedness, they easily form a rule of emotion work in that specific classroom. Interactional studies have shown that one of the characteristics of displays of affect is their vulnerability to emotional contagion (Sorjonen \& Peräkylä 2012). Emotional contagion means that in interactions emotions are usually shared by participants after one participant has offered public forms of emotion for others to attend to (Peräkylä 2012). Referring to these observations, we suggest that displays of emotions, expressed in the details of interaction and observable not only to the addressee but to all present participants, can in time become shared by other participants. In other words, we want to suggest that in mathematics education positive and negative attitudes toward mathematics are, at least partly, formulated in the details of everyday interaction in classrooms. We argue, together with many other researchers of mathematics education, that emotion work in learning mathematics is crucial (e.g., Frenzel, Pekrun \& Goetz 2007). We see as our original contribution to this field of research the identification of the emotion work in the verbal and non-verbal practices of teachers and students in classroom interaction.

In our analysis, we found characteristics of emotion work in classroom interaction, based on the characteristics of the question and the local verbal and embodied practices teachers used in responding to incorrect answers. For example, answering incorrectly certain routine questions presented in a series of similar kinds of questions can be treated as a mistake without going into the details of pupil reasoning, and responded to by humorous turns that convey positive emotions (example 1). This led to active turn-taking and pupil involvement in the interaction. We also analyzed an episode in which the teacher treated an incorrect answer by the pupil quite differently. In extract 2, the pupil and the teacher displayed facial expressions, gestures, and verbal contributions that pointed at problems after offering an incorrect answer. After some confusion, the teacher allocated the turn to another pupil. Our third example illustrated a case in which the teacher was involved in intensive interaction with a pupil. Extract 3 showed how the longish negotiation between the teacher and the pupil led to several displays of emotion, including the agitated exclamation of disappointment by the pupil. In this episode, the teacher responded immediately to the displays of pupil emotion, and the episode ended with satisfaction from the point of view of problem solving. Nevertheless, at some points the pupil's patience was tested, and his task solving wavered on the edge of failure. Based on the analysis of these examples, it seems to us that it is important for the teacher to communicate the message that incorrect answers are not to be avoided but to be treated as normal, appropriate student contributions. This attitude helps students create positive attitudes and self-beliefs, and fosters teaching and learning, even if the problem of negative attitudes and self-beliefs is much more complicated than what can be revealed in studies on classroom interaction.

To conclude, we hope that our detailed analysis of incorrect pupil answers and teacher evaluative responses to them, conducted through verbal and non-verbal practices, can offer new knowledge for teachers and teacher educators about the consequences of those small but important pedagogical decisions delivered during teaching. It is our wish that understanding the significance of emotion work in classrooms can help teachers in their efforts to support pupils' development in seeing themselves as capable learners in the field of mathematics. We also hope that our analysis will 
encourage researchers of mathematics education to pay more attention to emotional work and displays of emotion in and through the details of pedagogic interaction in classrooms.

\section{References}

Barwell, R. (2003). Patterns of attention in the interaction of a primary school mathematics student with English as an additional language. Educational Studies in Mathematics, 53, 35-59.

Bauersfeld, H. (1988). Interaction, construction, and knowledge. Alternative perspectives for mathematics education. In D. A. Grouws \& T. J. Cooney (Eds.), Perspectives on research on effective mathematics teaching: Research agenda for mathematics education (Vol.1, pp.27-46). Reston, VA: NCTM and Lawrence Erlbaum Associates.

Brown, P. \& Levinson, S. (1987). Politeness: Some universals of language usage. Cambridge: Cambridge University Press.

Cekaite, A. (2012). Affective stances in teacher-novice student interaction: language, embodiment, and willingness to learn in a Swedish primary classroom. Language in Society, 41, 641-670.

Drew, P. (1981). Adults' Corrections of Children's Mistakes: A Response to Wells and Montgomery. In P. French \& M. Maclure (Eds.), Adult-Child Conversation (pp. 244-267). London: Croom Helm.

Emanuelsson, J. \& Sahlström, F. (2008). The price of participation: Teacher control versus student participation in classroom interaction. Scandinavian Journal of Educational Research, 52(2), 205-223.

Evans, J., Morgan, C. \& Tsatsaroni, A. (2006). Discursive Positioning and Emotion in School Mathematics Practices. Educational Studies in Mathematics, Special Issue on Cognition and Affect in Mathematics Classrooms, 63(2), 209-226.

Forrester, M.A \& Pike, C.D. (1998). Learning to estimate in the mathematics classroom: a conversation analysis approach. Journal of Research in Mathematics Education, 29(3), 334-356.

Frenzel, A. C., Pekrun, R. \& Goetz, T. (2007). Perceived learning environment and students' emotional experiences: A multilevel analysis of mathematics classrooms. Learning and Instruction, 17(5), 478-493.

Goodwin, C. \& Heritage, J. (1990). Conversation analysis. Annual Review of Anthropology, 19, $283-307$.

Goodwin, M.H., Cekaite, A. \& Goodwin, C. (2012). Emotion as stance. In A. Peräkylä and M.-L. Sorjonen (Eds.), Emotion in interaction (pp. 4-41). Oxford: Oxford University Press.

Haakana, M. (2001). Laughing as patient's resource: Dealing with delicate aspects of medical interaction. Text, 21, 187219.

Haakana, M. (2011). "Mitä” ja muut avoimet korjausaloitteet [Mitä ('what') and other open class repair initiators in Finnish interactions]. Virittäjä, 115(1), 36-67

Hannula, M.S. (2012). Exploring new dimensions of mathematics-related affect: embodied and social theories. Research in Mathematics Education, 14(2), 137-161.

Harrison, L. J., Clarke, L. \& Ungerer, J. A. (2007). Children's drawings provide a new perspective on teacher-child relationship quality and school adjustment. Early Childhood Research Quarterly, 22, 55-71.

Hellermann, J. (2003). The interactive work of prosody in the IRF exchange: Teacher repetition in feedback moves. Language in Society, 32(1), 79-104.

Heritage, M. \& Heritage, J. (2013). Teacher questioning: the epicenter of instruction and assessment. Applied Measurement in Education, 26(3), 176-190. 
Hochschild, A.R. (2003). The managed heart: Commercialization of human feeling. Berkeley: University of California Press.

Ingram, J. (2012). Whole class interaction in the mathematics classroom: a conversation analytic approach. $\mathrm{PhD}$ thesis. University of Warwick. http://wrap.warwick.ac.uk/49627/1/WRAP_THESIS_Ingram_2012.pdf. Accessed 27 $7^{\text {th }}$ October 2013.

Järvelä, S., Järvenoja, H. \& Veerman, M. (2008). Understanding the dynamics of motivation in socially shared learning. International Journal of Educational Research, 47, 122-135.

Kaasila, R., Hannula, M. S., Laine, A., \& Pehkonen, E. (2008). Evaluating admission procedures for teacher education in Finland. Teaching mathematics and computer science, 6(1), 231-243.

Kärkkäinen, E. (2006). Stance taking in conversation: From subjectivity to intersubjectivity. Text and Talk, 26(6), 699-731.

Koole, T. (2012a). Teacher evaluations: assessing 'knowing', 'understanding', and ‘doing'. In G. Rasmussen, C.E. Brouwer \& D. Day (Eds.), Evaluating Cognitive Competences in Interaction (pp. 43-66), Amsterdam: Benjamins.

Koole, T. (2012b). The epistemics of student problems: explaining mathematics in a multilingual class. Journal of Pragmatics, 44, 1902-1916.

Kääntä, L. (2010). Teacher turn-allocation and repair practices in classroom interaction. A multisemiotic perspective. Jyväskylä studies in humanities 137. University of Jyväskylä. https://jyx.jyu.fi/dspace/handle/123456789/22993. Accessed $2^{\text {nd }}$ December 2013.

Lemke, J.L. (1990). Talking science: Language, learning and values. New York: Ablex.

Macbeth, D. (2003). Hugh Mehan's learning lessons reconsidered: On the differences between the naturalistic and critical analysis of classroom discourse. American Educational Research Journal 40(1), 239-280.

Macbeth, D. (2004). The relevance of repair for classroom correction. Language in Society, 33(5), 703-736.

Mehan, H. (1979). Learning Lessons. Social Organization in the Classroom. Cambridge: Harvard University Press.

Mullis, I.V.S., Martin, M.O., Foy, P., \& Arora, A. (2012). TIMSS 2011 International Results in Mathematics. Chestnut Hill, MA: TIMSS \& PIRLS International Study Center, Boston College.

Mushin, I., Gardner, R. \& Munro, J.M. (2013). Language matters in demonstrations of understanding in early years mathematics assessment. Mathematics Education Research Journal, 25, 415-433.

Mägi, K., Lerkkanen, M-K., Poikkeus, A-M., Rasku-Puttonen, H., \& Kikas, E. (2010). Relations Between Achievement Goal Orientations and Math Achievement in Primary Grades: A Follow-Up Study. Scandinavian Journal of Educational Research, 54(3), 295-312.

Nathan, M.J. \& Kim, S. (2009). Regulation of teacher elicitations in the mathematics classroom. Cognition and Instruction, 27(2), 91-120.

NC (2004). National Core Curriculum for Basic Education 2004. Helsinki: The National Board of Education.

Ochs, E. (1996). Linguistic resources for socializing humanity. In J. Gumperz \& S. Levinson (Eds.), Rethinking linguistic relativity (pp. 407-437). New York: Cambridge University Press.

OECD (2010). PISA 2009 Results: What Students Know and Can Do - Student Performance in Reading, Mathematics and Science. Volume I. http://dx.doi.org/10.1787/9789264091450-en. Accessed 10 ${ }^{\text {th }}$ November 2013. 
Peräkylä, A. (2012). Epilogue: What does the study of interaction offer to emotion research? In A. Peräkylä and M.-L. Sorjonen (Eds.), Emotion in interaction (pp. 274-289). Oxford: Oxford University Press.

Peräkylä, A. \& Ruusuvuori, J. (2012). Facial expression and interactional regulation of emotion. In A. Peräkylä and M.L. Sorjonen (Eds.), Emotion in interaction (pp. 64-91). Oxford: Oxford University Press.

Potter, J. (2006). Cognition and conversation. Discourse Studies, 8(1), 131-140.

Potter, J. and Wetherell, M. (1987). Discourse and Social Psychology: Beyond Attitudes and Behaviour. London: Sage.

Reis, G. \& Barwell, R. (2013). The intractional accomplishment of not knowing in elementary school science and mathematics: implications for classroom performance assessment practices. International Journal of Science and Mathematics Education ,11, 1067-1085.

Roth, W.M. \& Gardener, R. (2012). "They gonna explain us what makes a cube a cube” Geometrical properties as contingent achievement of sequentially ordered child-centered mathematics lessons. Mathematics Education Research Journal, 24, 323-346.

Ruusuvuori, J. (2013). Emotion, affect and conversation. In J. Sidnell \& T. Stivers (Eds.) The handbook of conversation analysis (pp. 330-349). Chichester, UK: Wiley-Blackwell.

Sahin, A. \& Kulm, G. (2008). Sixth grade mathematics teachers' intentions and use of probing, guiding, and factual questions. Journal of mathematics teacher education, 11(3), 221-241.

Schegloff, E.A. (2006). Sequence organization in interaction. A primer in conversation analysis. Cambridge: Cambridge University Press.

Sandlund, E. (2004). Feeling by doing. The social organization of everyday emotions in academic talk-in-interaction. Karlstad: Karlstad University Studies.

Schegloff, E. A., Jefferson, G. \& Sacks, H. (1977). The preference for self-correction in the organization of repair in conversation. Language, 53(2), 361-382.

Seedhouse, P. (2004). The interactional architecture of the language classroom. A conversation analysis perspective. Oxford: Blackwell.

Sorjonen, M.-L. \& Peräkylä, A. (2012). Introduction. In A. Peräkylä and M.-L. Sorjonen (Eds.), Emotion in interaction (pp. 3-15). Oxford: Oxford University Press.

Tainio, L. (2012). Prosodic imitation as a means of receiving and displaying critical stance in classroom interaction. Text and Talk, 32(4), 547-568.

Tuohilampi, L. \& Hannula, M. S. (2013). Matematiikkaan liittyvien asenteiden kehitys sekä asenteiden ja osaamisen välinen vuorovaikutus 3., 6. ja 9. luokalla. In J. Metsämuuronen (Ed.) Perusopetuksen matematiikan oppimistulosten pitkittäisarviointi vuosina 2005-2012 (pp. 231-253). Helsinki: Opetushallitus. ${ }^{3}$

\section{Appendix 1}

\footnotetext{
${ }^{3}$ English summary on p. 17

http://www.oph.fi/download/150841_Perusopetuksen_matematiikan_oppimistulosten_pitkittaisarviointi_vuosina_2 005.pdf
} 
Transcription conventions follow the tradition of conversation analysis. The adopted transcription conventions are the following:

$\begin{array}{ll}. /, / ? & \text { Falling/level/rising intonation } \\ - & \text { Cut-off } \\ \uparrow / \downarrow & \text { Change in pitch height: higher/lower than preceding speech } \\ ></<> & \text { Faster/slower tempo } \\ : & \text { Sound stretch } \\ \text { yea } & \text { Underline: stress of the sound } \\ \text { CAP } & \text { Loud voice } \\ (.) & \text { Pause, less than } 0.3 \mathrm{~s} \\ (0.5) & \text { Length of pause } \\ \text { hh .hh } & \text { Out-breath/in-breath } \\ {[\text { ] }} & \text { Overlap } \\ = & \text { Latching of turns } \\ \text { he he } & \text { Laughter } \\ \text { s(h)o } & \text { Word pronounced through laughter } \\ \text { " }, & \text { Reading aloud } \\ ((\text { holding a book) ) Non-verbal activities are in double parentheses }\end{array}$

